\title{
GASTRIC STUMP MUCOSA: is there a risk for carcinoma?
}

\author{
Adriana Vaz SAFATLE-RIBEIRO, Ulysses RIBEIRO Jr., \\ Paulo SAKAI, Kyoshi IRIYA, \\ Shinichi ISHIOKA and Joaquim GAMA-RODRIGUES
}

\begin{abstract}
Background - Patients who underwent partial gastric resections are at an increased risk for the development of cancer in the gastric remnant. Aim - To assess the long-term patients who underwent surgical treatment for peptic ulcer disease through endoscopic and pathologic evaluation of the gastric stump mucosal alterations. Patients and Methods Between 1987 and 1990, 154 patients (mean = 20.4 years after gastrectomy) were evaluated by upper digestive endoscopy with multiple biopsies and pathological examination. Results - Endoscopic alterations were present in 111 patients (72.1\%). The commonest pathologic alterations were foveolar hyperplasia, intestinal metaplasia and cystic dilation. Severe dysplasia was noted in two (1.25\%) and carcinoma in 13 (8.4\%) of the cases. In four patients (3.8\%) the endoscopic findings did not show any evidence of tumors, however they were detected due to multiple biopsies and histologic studies. Conclusions Surveillance of these patients with endoscopy and multiple biopsies may provide the means to diagnose tumors at an early stage, but the cost benefit ratio of surveillance requires further study.
\end{abstract}

HEADINGS - Gastrectomy. Stomach neoplasms, diagnosis. Gastric stump. Peptic ulcer, surgery.

\section{INTRODUCTION}

During the first half of this century, partial gastrectomy followed by several types of reconstruction, became the predominant treatment for peptic ulcer disease. The disruption of the integrity of the stomach has been associated with an increased risk for development of cancer in the gastric remnant ${ }^{7}$, 26, 27, 30, 44). BALFOUR ${ }^{(2)}$ in 1922, was the first to describe adenocarcinoma of the gastric stump. This entity is defined as a primary carcinoma arising from the gastric remnant at least 5 years after surgery for benign peptic disease. A minimal latency of 5 years is included in the definition to avoid misdiagnosis ${ }^{(12)}$.

While specific factors responsible for the pathogenesis of gastric stump carcinoma (GSCA) are not known, several theories have been formulated to explain this phenomenon. These potential mechanisms include: 1) enterogastric reflux of bile acids; 2) hypo or achlorhydria with subsequent bacterial overgrowth and increased exposure to carcinogenic agents such as bile acids or nitrosamines; 3 ) response to increased proliferation caused by chronic gastritis; 4) hormonal regulation effect following vagotomy and hypogastrinemia; 5) effect of Helicobacter pylori; and 6) consequence of suture ${ }^{(1,}$ $10,17,20,23,28,33,35,40,45)$. Studies on animal models showed that the newly created environment of the remnant stomach after resection, especially reflux of the duodenal contents, may act as a promoting factor ${ }^{(5,16,32)}$.

The gastric mucosa undergoes marked morphologic changes in most patients after gastric surgery in a time dependent manner ${ }^{(32)}$. These histologic alterations observed from tissues collected during endoscopic examination have been seldom reported in the literature, and the true rate of gastric stump carcinoma is still a matter of discussion. Moreover, many features of GSCA remain controversial. The frequency, site, interval following gastrectomy, location of the peptic disease, clinical features, type of tumor and risk rate vary according to the populations studied ${ }^{(32)}$. Therefore, the purpose of this long-term study was to investigate the patients who underwent gastrectomy for peptic ulcer disease, 
through endoscopic and pathologic assessment of the gastric stump mucosal alterations.

\section{MATERIAL AND METHODS}

Between 1987 and 1990, 154 patients with more than 10 years following surgical treatment for peptic ulcer disease were evaluated by upper digestive endoscopy and multiple biopsies. The biopsies were obtained from body (anterior and posterior walls), anastomotic area (lesser and greater curvature) and from any endoscopic lesion. Ninety-two patients were male and the mean age at the time of endoscopic examination was 61.9 (range $=39$ to 93 years). Billroth II reconstructions were performed in 137 (89\%), Billroth I in 16 (10.4\%) and Roux-in-Y in 1 $(0.6 \%)$. The postoperative interval varied from 10 to 50 years $($ mean $=$ 20.4 years) postgastrectomy. The mucosal alterations were categorized in: superficial chronic gastritis, atrophic gastritis, foveolar hyperplasia, intestinal metaplasia, cystic dilatation, adenoma, dysplasia and carcinoma.

\section{RESULTS}

A total of 610 biopsies from 154 patients was performed, and was the basis for analysis. In 23 (15\%) patients, the endoscopic examination was performed only for postgastrectomy surveillance, while in 131 (85\%) because of dyspeptic symptoms. Endoscopic alterations were present in $111(72.1 \%)$ of the patients and absent in $43(27.9 \%)$. There was no correlation between the symptoms, the endoscopic findings and the histopathologic results.

The mucosal alterations of the gastric stump epithelium are listed in Table 1. No patient had normal epithelium by histopathologic examination. All patients had some degree of gastritis, varying from superficial to atrophic. The commonest alterations were foveolar hyperplasia, intestinal metaplasia and cystic dilatation. Severe dysplasia and adenocarcinoma were noted in $2(1.25 \%)$ and $13(8.4 \%)$ of the cases, respectively (Table 1).

TABLE 1 - Mucosal alterations present in 154 long-term postgastrectomy patients

\begin{tabular}{lcc}
\hline Histologic changes & Number & $\mathbf{\%}$ \\
\hline Chronic superficial gastritis & 71 & 46.1 \\
Chronic atrophic gastritis & 26 & 16.9 \\
Foveolar hyperplasia & 57 & 37.0 \\
Intestinal metaplasia & 87 & 56.5 \\
Cystic dilatation & 67 & 43.5 \\
Adenoma & 5 & 3.2 \\
Benign ulceration & 11 & 7.1 \\
Dysplasia & 2 & 1.3 \\
Adenocarcinoma & 13 & 8.4 \\
\hline
\end{tabular}

The main clinical and endoscopic characteristics of the GSCA patients are presented in Table 2. Eight patients were men and the mean age was 64.8 years $(95 \%$ confidence interval $=59.5-70.2)$. All patients had their tumors diagnosed after a minimum period of 15 years following gastrectomy (mean $=21.15$ years, $\mathrm{SD}=9.62,95 \%$ confidence interval $=15.3-26.9)$. Nine patients underwent Billroth II reconstruction and four Billroth I. The predominant symptom was epigastric pain. In four patients $(3.8 \%)$, the endoscopic findings did not show any evidence of malignant lesions, undervent collected several biopsies during the upper gastrointestinal endoscopy, and the pathologic examination confirmed the presence of carcinoma. The anastomotic area was the preferential tumor growth site in seven $(53.8 \%)$ patients, followed by cardia in four and body in two. According to Laurén's classification, the tumors were intestinal type in seven cases $(53.8 \%)$ and diffuse in six (46.2\%) (Table 2).

\section{DISCUSSION}

The postoperative interval is the most important determinant of cancer risk following gastrectomy $(8,24,25,32,39,41,42,43)$. As time goes on, the pronounced mucosal alteration increases parallel to the increasing cancer risk

A variety of mucosal alterations could be observed in this patient population, including chronic superficial gastritis, atrophic gastritis, foveolar hyperplasia, intestinal metaplasia, cystic dilatation, ulceration, dysplasia, adenoma, and at last carcinoma. GSCA invariably develops in gastric epithelium that has undergone profound changes including atrophy, intestinal metaplasia, cystic dilatation of glands, and foveolar hyperplasia, concurrent with paucity of inflammatory cell infiltrate ${ }^{(6)}$. These changes are most prominent in the stimuli area ${ }^{(25)}$ but cardia and fundus can be the site of carcinoma as well. In fact, as we demonstrated by our data, no patient who underwent partial gastrectomy had a completely normal gastric mucosa ${ }^{(11,34)}$. Many of these changes were so marked that they could be recognized endoscopically.

Cystic dilatation of gastric glands is very common in gastric stump patients and seems to be a tissue reaction to this different environment ${ }^{(29)}$. Foveolar hyperplasia appears topographically related to the anastomosis after partial gastrectomy. The association of these two lesions has been described as gastritis cystic polyposa ${ }^{(19)}$. It is held to be a product of hyper-regeneration of the gastric mucosa under injurious influence of bile reflux. Postgastrectomy patients with foveolar hyperplasia have shown an increased proliferative activity and a luminal expansion of the proliferative compartment of the gastric pits, compatible with a precancerous potential ${ }^{(18,25)}$.

Atrophic changes are frequent, with loss of the chief and parietal cell mass. A relationship between chronic atrophic gastritis and gastric cancer has been reported ${ }^{(36,37)}$. A 5-6-fold increase in risk of gastric 
TABLE 2 - Clinical and endoscopic characteristics of 13 patients with gastric stump cancer

\begin{tabular}{|c|c|c|c|c|c|c|c|c|}
\hline Patient & Gender & Age & $\begin{array}{c}\text { Surgical } \\
\text { technique }\end{array}$ & $\begin{array}{c}\text { Postoperative } \\
\text { interval }\end{array}$ & Symptoms & $\begin{array}{l}\text { Endoscopic } \\
\text { findings }\end{array}$ & $\begin{array}{c}\text { Tumor } \\
\text { site }\end{array}$ & Histology \\
\hline 1 & Male & 55 & BII & 15 & Epigastric pain & Gastritis & Anastomosis & Intestinal \\
\hline 3 & Female & 63 & BII & 20 & Epigastric pain & Gastritis & Anastomosis & Diffuse \\
\hline 4 & Female & 81 & $\mathrm{BI}$ & 25 & Anemia & Gastritis & Anastomosis & Intestinal \\
\hline 7 & Male & 75 & BII & 44 & Anemia & Neoplasia & Anastomosis & Intestinal \\
\hline 8 & Female & 66 & $\mathrm{BI}$ & 20 & Epigastric pain & Neoplasia & Body & Intestinal \\
\hline 9 & Female & 71 & BI & 16 & Weight lost & Neoplasia & Cardia & Diffuse \\
\hline 10 & Male & 59 & BI & 15 & Anemia & Neoplasia & Anastomosis & Intestinal \\
\hline
\end{tabular}

cancer has been observed in patients with endoscopically diagnosed atrophic gastritis compared to those without atrophy ${ }^{(15)}$.

Intestinal metaplasia is a frequent accompaniment of chronic atrophic gastritis and is generally accepted to be a background for cancer development ${ }^{(21)}$. The most used classification ${ }^{(14)}$ defines the types of intestinal metaplasia as follows: I, presence of Goblet cells secreting acid sialomucins, Paneth cells are mature, non-mucous secreting absorptive cells; IIA, Goblet cells secreting sialomucins and sometimes sulphomucins, almost complete absence of Paneth cells and replacement of absorptive cells by columnar mucous cells secreting non-sulfated mucins; and IIB, the columnar mucous cells secrete predominantly sulphomucins. Intestinal metaplasia is more common in stomachs with a carcinoma than in those removed for benign lesions ${ }^{(11,21)}$. It is, however, found more often in patients having an intestinal type of gastric carcinoma than in those having a diffuse type carcinoma ${ }^{(11)}$. Type IIB intestinal metaplasia has a 5-fold increased risk of stomach cancer as compared with type $I^{(9)}$. While there is indisputable evidence of an association between intestinal metaplasia and chronic atrophic gastritis and gastric cancer, the high prevalence of these histological abnormalities and the low risk of cancer, limits its use as a marker of malignancy ${ }^{(4)}$.

Dysplasia may be defined as a partial loss of structural and functional resemblance to parent tissue. It can be the result of regenerative phenomena or of neoplastic changes. A regression of mild and moderate dysplastic lesions has been described ${ }^{(25,34)}$. Findings of dysplasia on random biopsy indicate a greater likelihood of development of GSCA and identify a subset of patients requiring more aggressive endoscopic surveillance $^{(13,22)}$. On the other hand, it is difficult to predict the time course during which dysplasia will evolve into overt carcinoma ${ }^{(13)}$.
The prevalence of carcinoma in the population studied was $8.4 \%$ and it is comparable with the literature. The prevalence of GSCA varies considerably from $0.8 \%$ to $8.9 \% \%^{(7,8,24,25,26,27,30,32,39,44)}$. This wide variation in the estimated prevalence can be explained by: the relatively small number of patients surveyed, the lack of appropriate control or comparison groups, incomplete follow-up, the surveillance technique used, geographic differences, the heterogeneity of surgical procedures and ulcer types in many of the $\operatorname{studies}^{(8,24,32)}$.

The male predominance $(2.25 \times 1)$ is in accordance with other authors $^{(30,32,44)}$. This may reflect the greater prevalence of ulcer disease and gastric cancer in males ${ }^{(26,30,32,44)}$. The mean age of patients with gastric cancer with or without previous resection is $\operatorname{similar}^{(7,26,44)}$. Cancer is generally diagnosed in the sixth or seventh decades. Some reports have stated that the gastric cancer from non-operated stomach contains a higher proportion of young or elderly patients than the GSCA population $^{(44)}$. This may relate to the population at risk for stump cancer and the required postoperative interval.

Patients with neoplasia had vague and non-specific symptoms, so we could not clinically differentiate from those without tumor. The most frequent symptoms are weight loss, early satiety, epigastric heaviness, esophageal symptoms, general weakness, fatigue, abdominal pain and dyspepsia ${ }^{(32,44)}$. Outlet obstruction and hemorrhage occur infrequently ${ }^{(44)}$. Therefore, special attention must be paid to the development of any new symptoms of dyspepsia in postgastrectomy patients.

The diagnosis is suggested occasionally by clinical symptoms and particularly by endoscopic or radiological examination, and is confirmed by hystopathological study of endoscopic biopsies. Radiological examination is limited by surgical distortion. In the course of endoscopy, 
multiple biopsy specimens should be collected, since neoplasia may be present in patients with a normal macroscopic appearance and is often multicentric; this routine, otherwise, facilitates the diagnosis of early gastric cancer of the stump ${ }^{(22,25)}$. Endoscopic ultrasonography can accurately estimate the extent of local invasion ${ }^{(38)}$. Computed tomography should be evaluated to determine if metastatic disease has developed and may contribute to analyze the extent of local spread.

The most prevalent location of stump cancer varies among different series. Our data showed the anastomosis to be the most common site while others found it to be the lesser curvature ${ }^{(7,19,25)}$. While small differences may exist, it is clear that the lesion may be located anywhere within the gastric remnant, including the cardia. It is necessary to routinely obtain multiple biopsies from the stoma area, the lesser and greater curvatures, and the anterior and posterior walls to increase the diagnostic rate ${ }^{(32)}$.

GSCA have been noted following Billroth I resection, gastroentericanastomosis and after vagotomy alone, but are considered more common after partial gastrectomy and gastrojejunal reconstruction (Billroth II) ${ }^{(32,44)}$. The increased enterogastric reflux and concurrent bacterial overgrowth in the adjacent blind loop may provide the basis for increased mucosal injury and cancer risk $^{(23,28)}$. Animal studies have confirmed the higher incidence of cancer after Billroth II than the other types of reconstruction ${ }^{(17,20,28)}$. Others have suggested, nonetheless, that this increased incidence may result from the fact that Billroth II operations were the surgical procedure of choice in many institutions around the world ${ }^{(44)}$.

There is evidence that there are two types of gastric carcinoma: one arising in normal mucosa (undifferentiated or diffuse); the other in areas of abnormal mucosa, particularly intestinal metaplasia (differentiated or intestinal). Intestinal type tumor is usually associated with an increased exposure to environmental factors ${ }^{(4)}$. Intestinal gastric cancer is predominantly a disease of the prepyloric antrum, and is more prevalent in high-risk areas such as Japan than in Western Europe or the U.S. ${ }^{(4,27)}$. Therefore, it might be expected that in view of the high incidence of mucosal abnormalities found in the gastric remnant that the differentiated or intestinal type of carcinoma would predominate. However, we have encountered an equal distribution of intestinal and diffuse type of gastric cancer in the stump, i.e., no preponderance of intestinal over diffuse type.

To achieve an early detection of GSCA many authors recommend repeated endoscopy beginning at 15 years following partial gastrectomy ${ }^{(7,22,25,26)}$. Surveillance biopsies should be taken in all areas of the remnant as multiple biopsies, especially from the anastomotic region ${ }^{(22,25,27)}$. Although the prognosis of advanced gastric stump cancer is poor, survival improves dramatically with early detection as demonstrated by endoscopic biopsy screening programs ${ }^{(22,25,27)}$. Early gastric cancer can be detected if the endoscopist is prepared to take multiple biopsies irrespective of the lack of symptoms and/or endoscopic appearance ${ }^{(7,25)}$. On the other hand, some authors reported that screening for gastric cancer after gastric surgery is generally not considered worthwhile because of the low detection rate ${ }^{(42)}$.

Our results demonstrated a high prevalence of carcinoma. Early tumor detection could be performed, even without a macroscopic lesion on the endoscopic examination, indicating the value of multiple biopsies in these patients.

Therefore, endoscopic screening would be beneficial if high cancer risk subsets of postgastrectomy patients could be delineated. Prospective studies using sensitive histology and genetic markers are needed to determine if surveillance can be cost effective $\mathrm{e}^{(3,18,31)}$

Safatle-Ribeiro AV, Ribeiro Jr U, Sakai P, Iriya K, Ishioka S, Gama-Rodrigues J. Mucosa do coto gástrico: risco para câncer? Arq Gastroenterol $2001 ; 38(4): 227-231$.

RESUMO - Racional-Pacientes submetidos a ressecção gástrica parcial apresentam risco aumentado de desenvolvimento de câncer de coto gástrico. Objetivo - Analisar, a longo prazo, as alterações da mucosa de pacientes submetidos previamente a tratamento cirúrgico, por úlcera péptica. Pacientes e Métodos - No periodo de 1987 a 1990, 154 pacientes (média de 20,4 anos após gastrectomia) foram analisados através de exames endoscópicos com múltiplas biopsias, e histopatológicos. Resultados - Alterações endoscópicas estiveram presentes em 111 pacientes $(72,1 \%$ ) e as mais freqüentemente encontradas foram: hiperplasia foveolar, metaplasia intestinal e dilatação cística. Displasia intensa foi diagnosticada em 2 (1,25\%) e carcinoma em 13 (8,4\%) dos casos. Em quatro pacientes (3,8\%), o método endoscópico não revelou lesão tumoral, contudo, foi detectada neoplasia no estudo histológico do material de biopsia. Conclusão - A vigilância dos pacientes gastrectomizados, através de procedimento endoscópico com múltiplas biopsias, pode diagnosticar neoplasia em estádio inicial; entretanto, novos estudos são necessários para se estabelecer a relação custo-benefício da referida estratégia de detecção.

DESCRITORES - Gastrectomia. Neoplasias gástricas, diagnóstico. Coto gástrico. Úlcera péptica, cirurgia. 


\section{REFERENCES}

1. Assad RT, Eastwood GL. Epithelial proliferation in human fundic mucosa after antrectomy and vagotomy. Gastroenterology 1980;79:807-11.

2. Balfour DC. Factors influencing the life expectancy of patients operated on for gastric ulcer. Ann Surg 1922;76:405-8.

3. Clarke MR, Safatle-Ribeiro AV, Ribeiro Jr U, Sakai P, Reynolds JC. Bcl-2 protein expression in gastric remnant mucosa and gastric cancer 15 or more years after partial gastrectomy. Mod Pathol 1997;10:1021-7.

4. Correa P. Precursors of gastric and esophageal cancer. Cancer 1982;50:2554-65.

5. Davenport HW. Effect of lysolecithin, digitonin and phospholipase A upon the dog's gastric mucosal barrier. Gastroenterology 1970;59:505-9.

6. Dixon MF, O'Connor HJ, Axon ATR, King RFJG, Johnston D. Reflux gastritis: distinct histopathological entity? J Clin Pathol 1986;39:524-30.

7. Domellof L, Eriksson S, Janunger K-G. Carcinoma and possible precancerous changes of the gastric stump after Billroth II resection. Gastroenterology 1977;73:462-8.

8. Dubrow R. Gastric cancer following peptic ulcer surgery. J Natl Cancer Inst 1993;85:1268-70

9. Filipe MI, Munoz N, Matko I, Kato I, Pompe-Kirn V, Jutersek A, Teuchemann S, Benz M, Prijon T. Intestinal metaplasia types and the risk of gastric cancer: a cohort study in Slovenia. Int J Cancer 1994;57:324-9.

10. Fisher SG, Davis F, Nelson R, Weber L, Goldberg J, Haenszel W. A cohort study of stomach cancer risk in men after gastric surgery for benign disease. J Natl Cancer Inst 1993;85:1303-10.

11. Geboes K, Rutgeerts P, Broeckaert L, Vantrappen G, Desmet V. Histologic appearances of endoscopic gastric mucosal biopsies 10-20 years after partial gastrectomy. Ann Surg 1980;192:179-82.

12. Helsingen N, Hillestad L. Cancer development in the gastric stump after partial gastrectomy for ulcer. Ann Surg 1956;143:173-9.

13. Holstein CS, Hammar E, Eriksson S, Huldt B. Clinical significance of dysplasia in gastric remnant biopsy specimens. Cancer 1993;72:1532-5.

14. Jass JR. Role of intestinal metaplasia in the histogenesis of gastric carcinoma. J Clin Pathol 1980;33:801-10.

15. Kato Y, Kitagawa T, Yanagisawa A, Kubo K, Utsude T, Hiratsuka H, Tamaki M, Sugano H. Site-dependent development of complete and incomplete intestinal metaplasia types in the human stomach. Jpn J Cancer Res 1992;83:178-83.

16. Kuwahara A, Saito T, Kobayashi M. Bile acids promote carcinogenesis in the remnant stomach of rats. J Cancer Res Clin Oncol 1989;115:423-8.

17. Langhans P, Heger RA, Hohenstein J, Bunte H. Gastric stump carcinoma - new aspects deduced from experimental results. Scand J Gastroenterol 1981;16(suppl 67):161-4.

18. Lipkin M. Biomarkers of increased susceptibility to gastrointestinal cancer: their development and application to studies of cancer prevention. Gastroenterology 1987;92:1083-6.

19. Littler ER, Gleibermann E. Gastritis cystica polyposa (gastric mucosal prolapse at gastroenterostomy site, with cystic and infiltrative epithelial hyperplasia). Cancer 1972;29:205-9.

20. Morgenstern L. Vagotomy, gastroenterostomy and experimental gastric cancer. Arch Surg 1968;96:920-3.

21. Morson BC. Intestinal metaplasia of the gastric mucosa. Br J Cancer 1955;9:365-6.

22. Mortensen NJMCC, Thomas WEG, Jones SM, Savage A. Endoscopic screening for premalignant changes 25 years after gastrectomy: results of a five-year prospective study. Br J Surg 1984;71:363-7.

23. Muscroft TJ, Deane SA, Youngs D, Burdon DW, Keighley MRB. The microflora of the postoperative stomach. Br J Surg 1981;68:560-4

24. Offerhaus GJA, Tersmette AC, Huibregtse K, Stadt JV, Tersmette KWF, Stijnen TH, Hoedemaeker PJ, Vandenbroucke JP, Tytgat GNJ. Mortality caused by stomach cancer after remote partial gastrectomy for benign conditions: 40 years of follow-up of an Amsterdam cohort of 2633 postgastrectomy patients. Gut 1988;29:1588-90.

25. Offerhaus GJA, Stadt JV, Huibregtse K, Tersmette AC, Tytgat GNJ. The mucosa of the gastric remnant harboring malignancy. Histologic findings in the biopsy specimens of 504 asymptomatic patients 15 to 46 years after partial gastrectomy with emphasis on nonmalignant lesions. Cancer 1989;64:698-703.

26. Ovaska JT, Havia TV, Kujari HP. Retrospective analysis of gastric stump carcinoma patients treated during 1946-1981. Acta Chir Scand 1986;152:199-204.

27. Pointner R, Schwab G, Konigsrainer A, Bodner E, Schmid KW. Gastric stump cancer: etiopathological and clinical aspects. Endoscopy 1989;21:115-9.

28. Reed PI, Smith PLR, Summers K, Haines K, Burgess BA, House FR, Walters CL. The influence of enterogastric reflux on gastric juice bacterial growth, nitrite and $\mathrm{N}$-nitroso compound concentrations following gastric surgery. Scand J Gastroenterol 1984;19(suppl 92):232-4.

29. Rubio CA, Ohman U. The intramucosal cysts of the stomach: I. In Swedish subjects with gastric or duodenal ulcers. Acta Pathol Microbiol Immunol Scand 1982;90:363-6.

30. Saegesser F, James D. Cancer of the gastric stump after partial gastrectomy (Billroth II principle) for ulcer. Cancer 29:1150-9.

31. Safatle-Ribeiro AV, Clarke MR, Ribeiro Jr U, Sakai P, Zary JT, Gama-Rodrigues J, Reynolds JC. Expression of p53, c-neu, TGF-alpha and PCNA in gastric epithelium 25 or more years following subtotal gastrectomy. Gastroenterology 1994;106:A433

32. Safatle-Ribeiro AV, Ribeiro Jr U, Reynolds JC. Gastric stump cancer: what is the risk? Dig Dis 1998;16:159-68.

33. Safatle-Ribeiro AV, Ribeiro Jr U, Clarke MR, Sakai P, Ishioka S, Garrido Jr AB, Gama-Rodrigues J, Safatle NF, Reynolds JC. Relationship between persistence of Helicobacter pylori and dysplasia, metaplasia, atrophy, inflammation, and cell proliferation following partial gastrectomy. Dig Dis Sci 1999; 44:243-52.

34. Savage A, Jones S. Histological appearances of the gastric mucosa 15-27 years after partial gastrectomy. J Clin Pathol 1979;32:179-86.

35. Savalgi RS, Corbishley CM, Caygill C, Hill M, Cook MG, Kirkham JS, Northfield TC. Relation between severity and extent of precancerous lesions in the postoperative stomach. Lancet 1990;336:413-6.

36. Sipponen P, Kekki M, Haapakoski J, Ihamaki T, Siurala M. Gastric cancer risk in chronic atrophic gastritis: statistical calculations of cross-sectional data. Int J Cancer 1985;35:173-7.

37. Siurala M, Lehtola J, Ihamaki T. Atrophic gastritis and its sequelae. Results of 19-23 years' follow-up examinations. Scand J Gastroenterol 1974;9:441-6.

38. Sivak MV. The challenge of endoscopic ultrassonography. Endoscopy 1994;26:759-63.

39. Stalsberg H, Taksdal S. Stomach cancer following gastric surgery for benign conditions. Lancet 1971;2:1175-7.

40. Tatsuta M, Yamamura H, Taniguchi H, Tamura H. Gastrin protection against chemically induced gastric adenocarcinomas in Wistar rats: histopathology of the glandular stomach and incidence of gastric adenocarcinoma. J Natl Cancer Inst 1982;69:59-63.

41. Tersmette AC, Offerhaus GJA, Tersmette KWF, Giardiello FM, Moore GW, Tytgat GNJ, Vandenbroucke JP. Meta-analysis of the risk of gastric stump cancer: detection of high risk patient subsets for stomach cancer after remote partial gastrectomy for benign conditions. Cancer Res 1990;50:6486-9.

42. Tersmette AC, Goodman SN, Offerhaus GJA, Tersmette KWF, Giardiello FM, Vandenbroucke JP, Tytgat GNJ. Multivariate analysis of the risk of stomach cancer after ulcer surgery in an Amsterdam cohort of postgastrectomy patients. Am J Epidemiol 1991;134:14-21.

43. Vecchia CL, Negri E, D'Avanzo B, Moller H, Franceschi S. Partial gastrectomy and subsequent gastric cancer risk. J Epidemiol Community Health 1992;46:12 4.

44. Viste A, Bjornestad E, Opheim P, Skarstein A, Thunold J, Hartveit F, Eide GE, Eide TJ, Soreide O. Risk of carcinoma following gastric operations for benign disease. A historical cohort study of 3740 patients. Lancet 1986;2:502-5.

45. Williamson RCN, Rainey JB. The relationship between intestinal hyperplasia and carcinogenesis. Scand J Gastroenterol 1984;19 Suppl 104:57-76.

Recebido em 14/11/2000 Aprovado em 3/1/2001. 